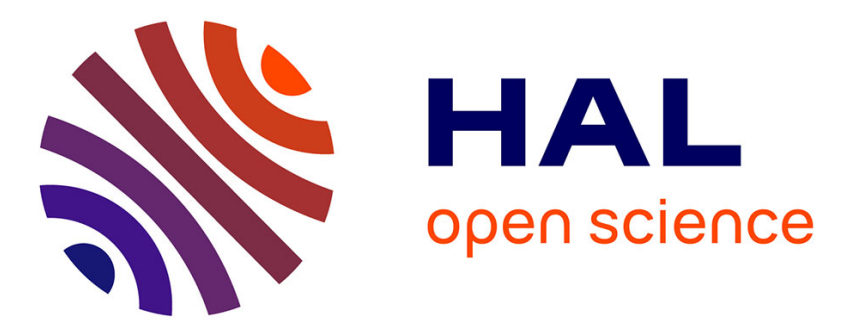

\title{
Stock and losses of trace metals from salt marsh plants
} Isabel Caçador, Miguel Caetano, Bernardo Duarte, Carlos Vale

\section{To cite this version:}

Isabel Caçador, Miguel Caetano, Bernardo Duarte, Carlos Vale. Stock and losses of trace metals from salt marsh plants. Marine Environmental Research, 2009, 67 (2), pp.75. 10.1016/j.marenvres.2008.11.004 . hal-00501984

\section{HAL Id: hal-00501984 \\ https://hal.science/hal-00501984}

Submitted on 13 Jul 2010

HAL is a multi-disciplinary open access archive for the deposit and dissemination of scientific research documents, whether they are published or not. The documents may come from teaching and research institutions in France or abroad, or from public or private research centers.
L'archive ouverte pluridisciplinaire HAL, est destinée au dépôt et à la diffusion de documents scientifiques de niveau recherche, publiés ou non, émanant des établissements d'enseignement et de recherche français ou étrangers, des laboratoires publics ou privés. 


\section{Accepted Manuscript}

Stock and losses of trace metals from salt marsh plants

Isabel Caçador, Miguel Caetano, Bernardo Duarte, Carlos Vale

PII:

S0141-1136(08)00245-6

DOI:

10.1016/j.marenvres.2008.11.004

Reference:

MERE 3302

To appear in:

Marine Environmental Research

Received Date:

4 August 2008

Revised Date:

13 November 2008

Accepted Date:

17 November 2008

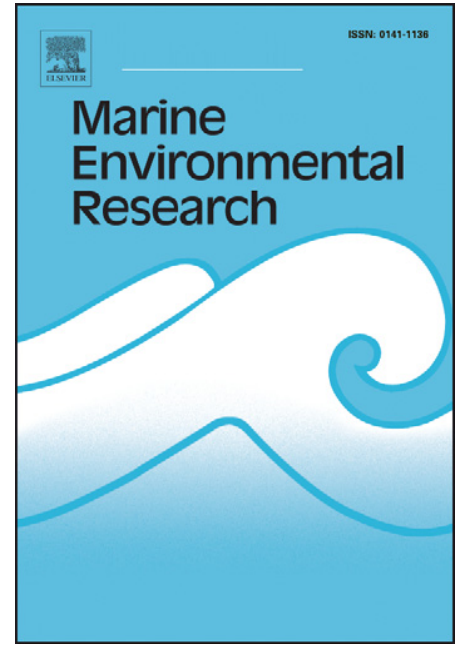

Please cite this article as: Caçador, I., Caetano, M., Duarte, B., Vale, C., Stock and losses of trace metals from salt marsh plants, Marine Environmental Research (2008), doi: 10.1016/j.marenvres.2008.11.004

This is a PDF file of an unedited manuscript that has been accepted for publication. As a service to our customers we are providing this early version of the manuscript. The manuscript will undergo copyediting, typesetting, and review of the resulting proof before it is published in its final form. Please note that during the production process errors may be discovered which could affect the content, and all legal disclaimers that apply to the journal pertain. 
Stock and losses of trace metals from salt marsh plants

Isabel Caçador ${ }^{\mathrm{a}}$, Miguel Caetano ${ }^{\mathrm{b}^{*}}$, Bernardo Duarte $^{\mathrm{a}}$ and Carlos Vale ${ }^{\mathrm{b}}$

${ }^{a}$ Institute of Oceanography, Faculty of Sciences, University of Lisbon, Rua Ernesto de Vasconcelos, Campo Grande 1749-016 Lisbon, Portugal

${ }^{\mathrm{b}}$ IPIMAR - National Institute of Biological Resources, Av. Brasília 1449-006, Lisbon, Portugal

* corresponding author (e-mail: mcaetano@ipimar.pt; Tlf: +351.213027057; Fax:

$+351.213015948)$ 


\section{ABSTRACT}

2 Pools of $\mathrm{Zn}, \mathrm{Cu}, \mathrm{Cd}$ and $\mathrm{Co}$ in leaf, stem and root tissues of Sarcocornia fruticosa, $S$.

3 perennis, Halimione portulacoides and Spartina maritima were analysed for a Tagus

4 estuary (Portugal) salt marsh. Pools of $\mathrm{Cu}$ and $\mathrm{Cd}$ in the salt marsh were higher in

5 spring/summer indicating a net uptake of these metals during the growing season.

6 Standing stocks of $\mathrm{Zn}, \mathrm{Cu}, \mathrm{Cd}$ and Co in leaf and stem biomass of S. fruticosa, $S$.

7 perennis and $H$. portulacoides showed a strong seasonal variation, with higher values

8 recorded in autumn. The metal-containing leaves and stems that shed in the autumn

9 become metal-containing detritus. The amount of this material washed out from the

10 total marsh area (200 ha) was estimated as $68 \mathrm{~kg}$ of $\mathrm{Zn}, 8.2 \mathrm{~kg}$ of Cu, $13 \mathrm{~kg}$ of Co and

$110.35 \mathrm{~kg}$ of $\mathrm{Cd}$. The high tidal amplitude, a branched system of channels and semidiurnal

12 tidal cycle greatly favour the export of the organic detritus to adjoining marsh area.

13

14

15 Keywords: halophytes, metals, detritus, salt-marshes, metal-containing litter 


\section{Introduction}

Salt marsh plants are widely recognized to influence the transfer of metals between the aquatic compartments (Rozema et al., 1985; Crowder, 1991). These metals may be immobilized and stored in belowground biomass, sediment or in aboveground tissues (Jacob and Otte, 2003; Weis and Weis, 2004). Several plant species have the remarkable ability to concentrate metals in their tissues and are therefore being used for phytoremediation proposes (Meagher, 2000; Williams, 2002). Plants included in that category have been widely studied and their capacity to accumulate metals in roots is well documented (Almeida et al., 2004; Cundy et al., 2005; Deng et al., 2006). Since most salt marsh plants show low translocation of metals to their aboveground tissues, they have been considered as a long-term sink (McFarlane et al., 2003; Fitzgerald et al., 2003). Nevertheless, some studies on natural marsh plants have shown that a small portion of the accumulated metals may be released back to the aquatic environment through salt glands in living leaves, according to the physiological and morphological properties of plants (Burke et al., 2000; Weis et al., 2002). Furthermore, during the seasonal life cycle of salt marsh plants aboveground plant portions die and fall to the sediment becoming organic-rich detritus (Giblin et al., 1980; Valiela et al., 1985; Weis and Weis, 2004). This detritus can be retained and/or exported out from the marsh according to the flooding regime, elevation gradient, marsh topography and wind (Halupa and Howes, 2004; Neckless and Neill, 2004). Flooding and wind increase the rate of mass loss from aboveground litter (Dame, 1982; Bouchard et al., 1998; Bouchard and Lefeuvre, 2000). Otherwise, detritus retention increases with the elevation gradient from low marsh (frequently inundated) to higher marsh area (Mitsch and Gosselink, 2000). The branched system of channels across that gradient also promotes the transfer of litter between marsh zones and the export to adjacent areas (Caçador et al., 2004). A number of studies have focused on in situ plant litter decay using nylon mesh litter bags (e.g. Valiela et al., 1985; Halupa and Howes, 2004). The decomposition of litter is strongly regulated by climate conditions, litter quality, sediment properties, bacterial and fungal populations (Valiela et al., 1985; Graça et al., 2000). Since metals in aboveground plant parts are likely to persist when tissues die and fall off, the leaching or retention of metals in decaying litter over time has been extensively investigated (Banus et al., 1974; Dorgelo et al., 1995; Zawislanski et al., 2001; Du Laing et al., 2006). Otherwise, metal-containing detritus can also be transported to adjacent marsh areas. The large majority of salt marsh ecosystems 
exported energy-rich substances (reduced nitrogen compounds, dissolved and particulate organic matter) to deeper waters (Mitsch and Gosselink, 2000; Valiela et al., 2004). Banus et al. (1974) highlight that substantial amounts of $\mathrm{Pb}$ associated with $S$. alterniflora litter may be removed by tides from the marsh surfaces. However, where metal-containing fertilizers were supplied to the marsh a minor export of $\mathrm{Pb}, \mathrm{Zn}$ and $\mathrm{Cd}$ associated with litter was obtained (Banus et al., 1975). Consequently, there is little agreement on the transfer of trace metals to marine environment across the detritus generated by salt marsh plants. The fate of detritus is crucial to the understanding of the metals budgets at the estuarine ecosystem level.

The aim of this work was to assess the budget of selected metals ( $\mathrm{Zn}, \mathrm{Cu}, \mathrm{Cd}$ and $\mathrm{Co}$ ) exported from a moderately contaminated salt marsh during a one-year growing season. While $\mathrm{Zn}$ and $\mathrm{Cu}$ are essential metals, and no metabolic functions are known for $\mathrm{Cd}$, less evidence exists on the beneficial effects of $\mathrm{Co}$. The partition of $\mathrm{Zn}, \mathrm{Cu}, \mathrm{Cd}$ and $\mathrm{Co}$ concentrations between aboveground plant parts and belowground biomass are also studied. We focused our study on the most common plants of south European salt marshes: Sarcocornia fruticosa, Sarcocornia perennis, Halimione portulacoides and Spartina maritima. The standing stock of metals was estimated for plants as a whole and also for the individual plant parts.

\section{Materials and methods}

\subsection{Study area}

The Tagus estuary is one of the largest on the Atlantic coast of Europe and subjected to high human pressure with ca. 4 million people living around it. Around $40 \%$ of the estuary is composed of intertidal mudflats and its southern and eastern shores contain extensive areas of salt marshes colonised mainly by Sarcocornia fruticosa (Caryophyllalles, Chenopodiaceae), Sarcocornia perennis (Caryophyllalles, Chenopodiaceae), Halimione portulacoides (Caryophyllalles, Chenopodiaceae) and Spartina maritima (Poales, Poaceae). One of the marshes (Rosário) located in the southern shoreline of the Tagus estuary (Figure 1) covers an area of 200 ha (Crespo, 1993) and is characterized by a typical zonation with homogeneous stands of $S$. maritima as a pioneer species, colonizing bare mud in the lower marsh area. Across the elevation $(20-50 \mathrm{~cm})$ transect pure stands of $H$. portulacoides follow $S$. maritima, while S. fruticosa and S. perennis are found in the upper salt marsh. This marsh is fully 
84 inundated twice a day by tidal action (2-4m of tidal amplitude) through a highly

85 branched system of channels that cross the elevation transect. These channels have 0.5

86 to $1.5 \mathrm{~m}$ depth promoting the inundation of the higher marsh even at low amplitude

87 tides. During the ebb tide water is drained into the channels due to the water table

difference. The Rosário marsh is located in the proximity of a heavy industrialised area

that includes several chemical plants. During the past four decades these industries

discharged effluents enriched in several contaminates directly into the estuary.

According to Vale (1990) both the semi-diurnal tidal inundation and the proximity to these pollution sources contribute to metal inputs to the Rosário salt marsh. Pore water depth profiles obtained from intertidal sediments will give erroneous information of the metals budgets introduced into the marsh due to post-depositional early diagenetic reactions (Shaw et al., 1990) associated with tidal flushing of pore water solutes (Caetano et al., 1995). Thus, in this particular situation it is inaccurate to estimate the amount of metals flushed to the estuary and establish the pools of metals introduced/retained in the marsh. However, available data on depth profiles of $\mathrm{Zn}, \mathrm{Cu}$, $\mathrm{Cd}$ and $\mathrm{Pb}$ in non-vegetated sediments showed that concentrations in the upper $10 \mathrm{~cm}$

100 layers are up two 10 times higher than pre-industrial levels (Caçador et al., 1993; 1996;

101 Caetano et al., 2007).

\subsection{Plant material and sampling}

104 Pure stands of S. fruticosa, S. perennis, H. portulacoides and S. maritima were sampled bimonthly at Rosário salt marsh at low tide across a growing season, from October 2001 to June 2002. The aboveground biomass was assessed for each species by clipping out five squares of $0.3 \times 0.3 \mathrm{~m}$, and storing in plastic bags. In the laboratory plant parts were washed with Milli-Q water (18.2 M $\Omega . \mathrm{cm})$ to remove dust and sediment, and separated into photosynthetic and non-photosynthetic tissues. Sarcocornia fruticosa and $S$. perennis do not have a true shoot system with leaves and stems. From these plants the swollen photosynthetic stems (referred to as "leaves" hereafter) were separated from the

112 dry perennial shoots (referred to as "stems" hereafter). The similar procedure was

113 followed for S. maritima where the tillers were divided in leaves and in non-

114 photosynthetic tissues (referred to as "stems" hereafter). Otherwise, the shoot system of

$115 H$. portulacoides allows separating leaves from stems. For all species, no flowering

116 plants were sampled. In each $0.3 \times 0.3 \mathrm{~m}$ square all the shedding parts of salt marsh

117 plants (hereafter referred as detritus) found on sediment surface were collected with 
118 tweezers and transported to the laboratory in plastic bags. This detritus material

119 corresponds to the dead plant portions retained within the salt marsh. Samples were

120 washed with Milli-Q water and oven dried at $60^{\circ} \mathrm{C}$ until constant weight. Five sediment

121 cores were taken at each study site using a core tube, $7 \mathrm{~cm}$ in diameter and $100 \mathrm{~cm}$ long.

122 Only the upper layer in each core $(0-25 \mathrm{~cm})$ was used since it contains the majority of

123 belowground components (Gross et al., 1991). The belowground biomass of this layer

124 was sorted out from the cores and carefully separated from the sediment under a flux of

125 Milli-Q water using a sieve with $212 \mu \mathrm{m}$ mesh size to remove any adhering particulate

126 matter. Plant parts were oven dried at $60^{\circ} \mathrm{C}$ and powdered in a grinding ball mill (Glen

127 CrestomMM2000) (Gross et al., 1991). Sediment samples were oven dried at $60^{\circ} \mathrm{C}$ until

128 constant weight, cleaned of roots with tweezers, passed through a $0.25 \mathrm{~mm}$ mesh,

129 homogenised and ground with an agate mortar (Caçador et al., 1999).

\subsection{Analytical Methods}

132 Redox potential (Eh) and $\mathrm{pH}$ of the sediment between the roots were measured in situ in

133 all sampling periods except October 2001. Five replicate measurements were obtained

134 between 10 and $15-\mathrm{cm}$ depth. The $\mathrm{pH}$ was measured using a combined glass electrode

135 with one $\mathrm{Ag} / \mathrm{AgCl}$ reference electrode while for Eh measurements a platinum electrode

136 with a calomel reference electrode was used. Values of redox potential were corrected

137 for the reference potential of $\mathrm{H}_{2}$. Pore water was extracted by centrifugation ( $3000 \mathrm{rpm}$,

$13810 \mathrm{~min}$ ) to measure salinity using a refractometer (Atago, S/Mill-E). Particle size (sand,

139 silt, or clay) in each sediment sample was determined by the pipette method (Gee and

140 Bauder, 1986). The organic matter content of the sediment was determined in dried

141 samples by loss of ignition (LOI) at $600{ }^{\circ} \mathrm{C}$ for 2 hours. Sediment samples $(\approx 100 \mathrm{mg})$

142 were digested with $10 \mathrm{~mL}$ of $\mathrm{HNO}_{3} / \mathrm{HCl}(3: 1 \mathrm{v} / \mathrm{v})$ at $130{ }^{\circ} \mathrm{C}$. This procedure was

143 repeated twice, as described by Otte (1991). Concentrations of $\mathrm{Zn}$ were determined by

144 flame atomic absorption spectrometry (FAAS) with an air-acetylene flame while levels

145 of $\mathrm{Cu}, \mathrm{Co}$ and $\mathrm{Cd}$ were determined by graphite furnace atomic absorption spectrometry

146 (GFAAS). Plant samples and detritus $(\approx 200 \mathrm{mg})$ were digested with $10 \mathrm{~mL}$ of

$147 \mathrm{HNO}_{3} / \mathrm{HClO}_{4}(7: 1 \mathrm{v} / \mathrm{v})$ at $130{ }^{\circ} \mathrm{C}$ according to the method described by Otte (1991).

148 Levels of $\mathrm{Zn}, \mathrm{Cu}, \mathrm{Co}$ and $\mathrm{Cd}$ were determined by GFAAS and detection limits were

$1490.01,0.10,0.05$ and $0.05 \mu \mathrm{g} \mathrm{g}^{-1}$, respectively, for all the analytical procedures used.

150 International certified reference materials of sewage sludge (CRM 145 and CRM 146)

151 and plant material (BCR 62- Olea europaea) were used to ensure accuracy of our 
152 procedure. For all metals investigated, obtained values were consistently within the

153 ranges of certified values $(p<0.05)$.

154 The area occupied by each plant species in Rosário salt marsh was estimated on the 155 basis of patches from aerial photographs scaling 1:2000. Halimione portulacoides

156 colonized 132 ha, the equivalent to $66 \%$ of the total salt marsh area (200 ha), $S$.

157 maritima and $S$. fruticosa occupied 37.6 and 28.2 ha, respectively and S. perennis was

158 found only in small patches within the marsh.

\subsection{Data analysis}

161 Statistical analysis was performed using a one-way analysis of variance to detect

162 differences between metal concentrations, plant type and dates. The same test was used

163 to look for differences in the sediment characteristics. One-way ANOVA and Newman-

164 Keuls multiple comparison tests were used to detect differences between standing

165 stocks of metals. To obtain homogeneity of variance, data were log-transformed (Sokal

166 and Rohlf, 1981).

\subsection{Estimation of aboveground plant detritus}

169 The difference between the maximum and the minimum metal standing stocks for

170 leaves and stems over the annual period of study, allows the estimation of aboveground net metal production of detritus (NMePD; $\mathrm{mol} \mathrm{m}^{-2}$ ) for each plant species (Caçador et al., 2004):

where $i$ is the plant species and $\mathrm{Me}_{\mathrm{A}-\mathrm{stk}}\left(\mathrm{mol} \mathrm{m}^{-2}\right)$ is the aboveground metal standing stock for that species. By using the surface area colonized by each plant species in the

178 Rosário marsh, the amount of metal in aboveground plant detritus produced in the total marsh area $\left(Q_{\mathrm{Me}} ; \mathrm{kg}\right)$ may be estimated by:

$$
Q_{\mathrm{Me}}=\sum \mathrm{NMePD}_{\mathrm{i}} A_{\mathrm{i}}
$$

183 where $i$ is the plant species and $A$ is the area colonized by each plant species $\left(\mathrm{m}^{2}\right)$. 


\section{Results and Discussion}

186

187

188

189

190

191

192

193

194

195

196

197

198

199

200

201

202

203

204

205

206

207

208

209

210

211

212

213

214

215

216

217

218

\subsection{Sediment characteristics}

Sediments from the upper layer $(0-25 \mathrm{~cm})$ were formed mainly of silt $(60 \pm 0.4 \%)$ and clays $(38 \pm 0.4 \%)$ in all plots studied and at all sampling times. This suggests that these plants grow in sediment with similar grain size and retained similar suspended matter (Salgueiro and Caçador, 2007). Pore water salinity varied within the salt marsh depending on vegetation species. Pore waters from sediments colonised by high marsh plants (S. fruticosa and S. perennis) contained more salts (salinity $=42 \pm 1.0$ and $41 \pm$ 1.7) than those from the lower marsh (H. portulacoides: salinity $=36 \pm 0.5$ and $S$. maritima: salinity $=31 \pm 0.2$ ). This difference was observed all over the seasonal survey, although salinity was lower in spring. A seasonal variation of $\mathrm{pH}$ was also observed, with lower values in the winter (Table 1). In a previous study, Sundby et al. (2003) showed that the release of oxygen by roots was lower in winter, changing the state of sediment to reduced conditions. Therefore, the reactions involving the $\mathrm{Fe}^{2+} / \mathrm{Fe}^{3+}$, $\mathrm{Mn}^{2+} / \mathrm{Mn}^{4+}$ and $\mathrm{S}^{2-} / \mathrm{SO}_{4}{ }^{2-}$ pairs prevail in the rhizosphere during the winter. As oxygen reduces in the rizosphere the decrease of $\mathrm{pH}$ appears to be related to the oxidation of iron sulphide compounds by Fe(III) organic complexes (Luther et al., 1996). Since no statistically significant differences of $\mathrm{pH}$ were found between plant species, early diagenetic reactions had similar consequences on sediment acidity and metal availability. The redox potential (Table 1) varied irregularly between plants and throughout the year with no seasonal pattern. These results are consistent with previous work done by Caçador et al. (1996) at several salt marshes in the Tagus estuary, showing that $\mathrm{pH}$ and Eh variations have no statistical consistency. No seasonal differences were found also for organic matter content. However, sediment colonized by S. maritima contained less organic matter $(13 \pm 1.0 \%)$ than the sediments from areas colonised by the other plant species ( $S$. fruticosa $=21 \pm 1.4 \%$; S. perennis $=20 \pm 1.6 \%$; and $H$. portulacoides $=20 \pm 1.5 \%$ ).

Mean concentrations of $\mathrm{Zn}, \mathrm{Cu}, \mathrm{Co}$ and $\mathrm{Cd}$ found in sediment between roots of the four plant species included in this study are shown in Table 2. Levels of $\mathrm{Cu}, \mathrm{Co}$ and $\mathrm{Cd}$ were relatively constant during the sampling period as can be inferred by the low standard deviations. Although an enhanced variability was found for $\mathrm{Zn}$ concentrations, the standard deviation never exceed $10 \%$ of the mean value. Moreover, no statistically significant differences were found among the metal $(\mathrm{Zn}, \mathrm{Cu}, \mathrm{Co}$ and $\mathrm{Cd})$ concentrations 
219 in sediments coming from areas colonised by the four plant species included in our

220 study. Lack of seasonal variation in the metal concentrations may be attributed to higher

221 non-reactive fraction of these metals in the solids (Caçador et al., 1996). However, it is

222 possible that variations within the sediment layer may have occurred, but this must have

223 been on a scale of a few centimetres only and could not be resolved by our sampling

224 methods.

225

\section{$226 \quad 3.2$ Plant biomass}

227 From October 2001 to February 2002, the plant biomass overall was larger in plots of $S$.

228 fruticosa, while areas with S. maritima had the lowest biomass values recorded from all

229 the plant species included in this study (Table 3). In April and June total biomass was

230 not statistically different for all the studied species. Root biomass may account for up to

$23180 \%$ (d.w.) of the total biomass. An exception was recorded in October for S. fruticosa,

232 when the aboveground biomass accounted for $50 \%$ of the total biomass. Presumably

233 because dead and live roots are not easily discerned, rather small seasonal variation

234 were observed in the biomass of roots, although higher values were found in the

235 summer for S. maritima and in spring for the other species. Results from aboveground

236 biomass showed statistically significant differences between plant species $(\mathrm{p}<0.05)$ and

237 also between leaf and stem biomass $(\mathrm{p}<0.05)$. Although both Sarcocornia species had

238 similar morphology, leaf and stem biomasses of S. fruticosa were up to one order of

239 magnitude higher than those calculated for $S$. perennis. The same difference was also

240 found by comparing aboveground plant parts biomass of $S$. fruticosa with those of $S$.

241 maritima and $H$. portulacoides (Table 3). Furthermore, a clear seasonal variation was

242 observed for leaf and stem biomass in all four species. Higher biomass values were

243 observed in October, followed by a logarithmic decrease. However, the decline of

244 biomass was more sharp for $S$. fruticosa (leaf: from $3516 \pm 341$ to $50 \pm 19 \mathrm{~g} \mathrm{~m}^{-2}$ and stem:

245 from $1919 \pm 195$ to $110 \pm 29 \mathrm{~g} \mathrm{~m}^{-2}$ ) than for S. perennis (leaf: from $167 \pm 39$ to $37 \pm 5 \mathrm{~g} \mathrm{~m}^{-2}$

246 and stem: from $425 \pm 40$ to $43 \pm 17 \mathrm{~g} \mathrm{~m}^{-2}$ ) and H. portulacoides (leaf: from $212 \pm 57$ to

$24746 \pm 3 \mathrm{~g} \mathrm{~m}^{-2}$ and stem: from $733 \pm 122$ to $180 \pm 49 \mathrm{~g} \mathrm{~m}^{-2}$ ). Leaf biomass in the latter species

248 was most reduced in December after some senescent leaves had fallen from the standing

249 stems. A different pattern was observed for S. maritima since aboveground biomass was

250 lower in December but increased afterwards. Differences in the phenology of plant

251 species attest to specific patterns of carbon allocation to the aboveground tissues, with 
S. perennis, S. fruticosa, and $H$. portulacoides promoting early leaf production when compared to S. maritima (Windham et al., 2003).

\subsection{Metal concentrations in plant parts}

256 Concentrations of $\mathrm{Zn}, \mathrm{Cu}, \mathrm{Co}$ and $\mathrm{Cd}$ in plant tissues of S. fruticosa, S. perennis, $H$.

257 portulacoides and S. maritima are presented in Table 4. Seasonal and tissue allocation

258 patterns of $\mathrm{Zn}, \mathrm{Cu}$, and $\mathrm{Cd}$ differed from $\mathrm{Co}$ in the four plant species studied under field

259 conditions. For all metals except Co, the concentrations in roots were, in general, up to

260 one order of magnitude higher than levels found in the aboveground tissues. The

261 partitioning indicates that for S. fruticosa, S. perennis, H. portulacoides and S. maritima

262 the dominant uptake of metals was via the root system with only small amounts being

263 translocated to the aerial plant parts (Fitzgerald et al., 2003; MacFarlane et al., 2003;

264 Weis and Weis, 2004). Metal concentrations in leaves showed no statistically significant

265 differences when compared to equivalent levels in stems within the same plant or

266 between plant species. The similarity of metal accumulation in aboveground plant parts

267 of S. maritima and of both Sarcocornia species may result from the undistinguished

268 shoot system of these plants. Moreover, we may suggest that photosynthetic tissues play

269 a minor role on the storage of metals in aboveground plant parts. No seasonal pattern

270 was observed for the concentration of essential elements, $\mathrm{Zn}$ and $\mathrm{Cu}$ in the aboveground

271 parts of the four species. However, concentrations of $\mathrm{Cd}$ in leaf and stem biomass of the

272 same plant species showed a distinct seasonal variation, with increased accumulation in

273 February. The accumulation of Co in the tissues of the studied plants showed a

274 distinctive pattern, quite different from that observed for the remaining elements. Up to

$27550 \%$ of the total metal pool was retained in the aboveground parts. While for $\mathrm{Zn}, \mathrm{Cu}$

276 and $\mathrm{Cd}$ the roots act as a barrier for upward translocation this retention was not

277 observed for Co. Detoxification of those metals by plants are associated with the

278 phytochelatins in plant cells (Zenk, 1996). However, Co does not activate the

279 phytochelatin synthase (Oven et al., 2002) suggesting that this metal may induce other

280 detoxification mechanisms or play a physiological role similar to that described for

281 algae. The coenzyme cobalamin has cobalt as component and is essential for Euglena

282 gracilis growth, being located in several subcellular compartments, including the

283 tilakoids of the chloroplasts (Marschner, 1995).

284

285

\subsection{Metal stocks in plants}


286 Our data of metal concentrations in plant parts combined with biomass allow us to

287 compare the standing stocks of given elements in whole plant tissues and subsets, or to

288 compare between plant species and for different seasons. Considering the standing

289 stocks in the whole plant structure for all species in our study (Figure 2), metal pools

290 were generally lower in S. maritima as a consequence of comparatively smaller biomass

291 values. Standing stocks of $\mathrm{Cu}$ and $\mathrm{Cd}$ were higher for all plants in spring/summer

$292(p<0.05)$ indicating a net uptake of these metals in the growing season. When standing

293 stocks of metals were analysed in leaves and stems two different patterns were observed

294 (Figure 3). In the cases of S. perennis, H. portulacoides and S. maritima, stems

295 contained comparatively higher aboveground standing stocks of $\mathrm{Zn}, \mathrm{Cu}, \mathrm{Co}$ and $\mathrm{Cd}$

296 ( $p<0.05)$ while for $S$. fruticosa leaves emerge as the major contributor $(p<0.05)$. These

297 different patterns observed for standing stocks are explained by the higher aboveground

298 biomass of $S$. fruticosa (Table 3). There were also differences in the seasonality of

299 aboveground metal standing stocks. While $S$. perennis, S. fruticosa and $H$.

300 portulacoides showed a strong seasonal variation with higher values occurring in the

301 autumn ( $p<0.05$; Figure 3), the standing stocks of metals in S. maritima were higher in

302 February $(p<0.05$; Figure 3$)$. The early leaf production of $S$. maritima seems to be

303 coupled to an increased transfer of some metals into the aboveground tissues.

304 Belowground standing stocks in all plant species showed small irregular variability

305 throughout the seasonal survey (not shown), but values were considerably higher than

306 aboveground. This result is consistent with other investigations elsewhere showing

307 difficulty in observing well-defined seasonal patterns for metal concentrations in roots

308 (Gleason et al., 1979; Heller and Weber, 1998; Windham et al., 2003).

\section{$310 \quad 3.5$ Metal containing detritus}

311 Metals in aboveground tissues are likely to remain when these tissues die and turn into

312 detritus. The seasonal variation of the metal standing stocks in S. perennis, S. fruticosa

313 and $H$. portulacoides was mainly associated with aboveground biomass production.

314 Therefore the aboveground plant detritus - QMe may be estimated for a growing

315 season using equations 1 and 2. Results show that plants in our study area (200 ha)

316 generate organic detritus containing $96 \mathrm{~kg}$ of $\mathrm{Zn}, 13 \mathrm{~kg}$ of $\mathrm{Cu}, 18 \mathrm{~kg}$ of Co and $0.51 \mathrm{~kg}$

317 of Cd during one growing season. However, the pool of organic material derived from

318 aerial plant parts greatly exceeds the litter pool found in the sediment surface. The

319 detritus on the sediment surface follows a seasonal pattern with higher values at the end 
320 of the growing season (S. fruticosa $-1020 \mathrm{~g} \mathrm{~m}^{-2} ;$ S. perennis $-212 \mathrm{~g} \mathrm{~m}^{-2} ; H$.

321 portulacoides $-134 \mathrm{~g} \mathrm{~m}^{-2} ;$ S. maritima $-45 \mathrm{~g} \mathrm{~m}^{-2}$ ) and a decrease in winter (S. fruticosa

$322-146 \mathrm{~g} \mathrm{~m}^{-2} ;$ S. perennis $-25 \mathrm{~g} \mathrm{~m}^{-2} ;$ H. portulacoides $-62 \mathrm{~g} \mathrm{~m}^{-2} ;$ S. maritima $-21 \mathrm{~g} \mathrm{~m}^{-}$

$323^{2}$ ). This is in line with the findings of Caçador et al. (2004) where more than $86 \%$ of the

324 produced carbon from aboveground plant parts was exported from two different salt

325 marshes in the Tagus estuary. The hydrological conditions of Rosário salt marsh

326 (branched system of channels and semidiurnal tidal cycle) greatly favour the transport

327 of organic detritus to adjoining marsh areas. The litter production may be estimated by

328 different methods (Bouchard and Lefeuvre, 2000), although all have limitations

329 (Hopksion et al., 1978). Thus, we chose the simple method, viz. the difference between

330 maximum and minimum litter pools (Caçador et al., 2004). By comparing the

331 aboveground biomass production (Table 3) with the litter pool we calculate that only

$3325 \%$ (S. maritima), $21 \%$ (H. portulacoides) $17 \%$ (S. perennis) and $46 \%$ (S. fruticosa) of

333 the detritus produced by aboveground plant parts remain at the site. By apply these

334 proportions to the pool of the metal-containing detritus $\left(Q_{M e}\right)$ we found that most of the

335 metal containing detritus was flushed out from the marsh. During one growing season

$33668 \mathrm{~kg}$ of $\mathrm{Zn}, 8.2 \mathrm{~kg}$ of $\mathrm{Cu}, 13 \mathrm{~kg}$ of $\mathrm{Co}$ and $0.35 \mathrm{~kg}$ of Cd was exported to areas

337 adjoining the Rosário salt marsh. This metal containing detritus may act as a source for

338 these metals before being buried in the sediments since they are easily degraded by

339 decomposers and weathering (Weis and Weis, 2004; Du Laing et al., 2006).

341 4. Conclusions

342 There is an important export of trace metals associated with marsh detritus to the

343 estuary, even considering that all plant species included in this study have much higher

344 belowground than aboveground biomass. The export route involves uptake of metals

345 from sediment by roots, translocation to the aerial parts of plants, and return to the soil

346 after senescence and fall of aerial plant parts. The major fraction of the metal-containing

347 detritus is not retained within the marsh. Therefore, when assessing remediation

348 techniques in a contaminated marsh we must take into account the balance between

349 retention and export of metals from the marsh, the biology of the plant species involved

350 and the marsh ecology.

351

352 Acknowledgments 
353 This study was supported by POCTI/PNAT/BIA/15035/99 and Programa Operacional

354 Ciência, Tecnologia, Inovação do Quadro Comunitário de Apoio III. The authors are 355 grateful to Ivan Valiela for the helpful comments.

\section{References}

358 Alongi, D., Wattayakorn, G., Botle, S., Tirendi, F., Payn, C., Dixon, P., 2004. Influence of roots and climate on mineral and trace element storage and flux in tropical mangrove soils. Biogeochemistry 69, 105-123.

Almeida, C., Mucha, A., Vasconcelos, M., 2004. Influence of the sea rush Juncus maritimus on metal concentration and speciation in estuarine sediment colonized by the plant. Environmental Science Technology 33, 3112-3118.

Banus, M., Valiela, I., Teal, J., 1974. Export of lead from salt marshes. Marine Pollution Bulletin 5, 6-9.

Banus, M., Valiela, I., Teal, J., 1975. Lead, zinc and cadmium budgets in experimentally enriched salt marsh ecosystems. Estuarine Coastal Marine Science 3, 421-430.

Bouchard, V., Creach, V., Lefeuvre, J., Bertru, G., Mariotti, A., 1998. Fate of plant detritus in a European salt marsh dominated by Atriplex portulacoides (L.) Aellen. Hydrobiologia 373/374, 75-87.

Bouchard, V., Lefeuvre, J., 2000. Primary production and macro-detritus dynamics in a European salt marsh: carbon and nitrogen budgets. Aquatic Botany 67, 23-42.

Burke, D., Weis, J., Weis, P., 2000, Release of metals by the leaves of the salt marsh grasses Spartina alterniflora and Phragmites australis. Estuarine Coastal Shelf Science 51, 153-159.

Caçador, I., Vale, C., Catarino, F., 1993. Effects of plants on the accumulation of Zn,

384 Caçador, I., Mascarenhas, I., Mascarenhas, P., 1999. Biomass of Spartina maritima, Halimione portulacoides and Arthrocnemum fruticosum in Tagus estuary salt 
marshes. Halophyte uses in different climates. Backhuys Publishers, Leiden, 105-112.

Caçador, I., Costa, A., Vale, C., 2004. Carbon storage in Tagus salt marsh sediments. Water Air Soil Pollution: Focus 4, 701-714.

Caetano, M., Fonseca, N., Cesário, R., Vale, C., 2007. Mobility of Pb in salt marshes recorded by total content and stable isotopic signature. Science Total Environment 380, 84-92.

Crespo, R., 1993. Cartografia do habitat potencial de Passeriformes no Estuário do Tejo por processamento digital de imagem. Degree Thesis FC - University of Lisbon, Lisbon.

Crowder, A., 1991. Acidification, metals and macrophytes, Environmental Pollution 71, 171-203.

Cundy, A., Hopkison, L., Lafite, R., Spencer, K., Taylor, J., Ouddane, B., 2005. Heavy metal distribution and accumulation in two Spartina sp.-dominated macrotidal salt marshes from the Seine estuary (France) and the Medway estuary (UK). Applied Geochemistry 20, 1195-1208.

Dame, R., 1982. The flux of floating macrodetritus in the North Inlet estuarine ecosystem, Marine Ecology Progress Series 16, 161-171.

Deng, H., Ye, Z., Wong, M., 2006. Lead and zinc accumulation and tolerance in populations of six wetland plants. Environmental Pollution 141, 69-80.

Dorgelo, J., Meester, H., Vanvelzen, C., 1995. Effects of diet and heavy metals on growth rate and fertility in deposit-feeding snail Potamopyrgus jenkinsi (Smith) (Gastropoda: Hydrobiidae). Hydrobiologia 316, 199-210.

Du Laing, G., Ryckegem, G., Tack, F., Verloo, M., 2006. Metal accumulation in intertidal litter through decomposing leaf blades, sheaths and stems of Phragmites australis. Chemosphere 63, 1815-1823

Fitzgerald, E., Caffrey, J., Nesaratnam, S., McLoughlin, P., 2003. Copper and lead concentrations in salt marsh plants on the Suir Estuary, Ireland. Environmental Pollution 123, 67-74.

Gee, G., Bauder, J., 1986. Particle size analysis. in Madison, USA: American Society of Agronomy-Soil Science Society of America eds. Methods of soil analysis. Part I - Physical and mineralogical method Agronomy Monograph. 9, 383-411. 
418 Giblin, A., Bourg, A., Valiela, I., Teal, J., 1980. Uptake and Losses of Heavy Metals in Sewage Sludge by a New England Salt Marsh. American Journal of Botany 67, $1059-1068$

Gleason, M., Drifmeyer, J., Zieman, J., 1979. Seasonal and environmental variation in $\mathrm{Mn}, \mathrm{Fe}, \mathrm{Cu}$ and $\mathrm{Zn}$ content of Spartina alterniflora. Aquatic Botany 7, 385-392.

Graça, M., Newell, S., Kneib, R., 2000. Grazing rates of organic matter and living fung biomass of decaying Spartina alterniflora by three species of salt-marsh invertebrates Marine Biology 136, 281-289

Gross, M., Hardisky, M., Wolf, P., Klemas, V., 1991. Relationship between aboveground and belowground biomass of Spartina alterniflora (smooth cordgrass) Estuaries 14, 180-191.

Halupa, P., Howes, B. 2004. Effects of tidally mediated litter moisture contents on decomposition of Spartina alterniflora and S. patens. Marine Biology 123, 379391.

Hopkinson, C., Gosselink, J., Parrondo, R., 1978. Aboveground production of seven marsh plant species in coastal Luisiana. Ecology 59, 760-769.

Jacob, D., Otte, M., 2003. Conflicting processes in the wetland plant rhizosphere: Metal retention or mobilization? Water Air Soil Pollution 3, 91-104.

Luther, G., Shellenbarger, P., Brendel, P., 1996. Dissolved organic Fe(III) and Fe(II) complexes in salt marsh porewaters. Geochimica Cosmochimica Acta 60, 951960.

Marschner, H., 1995. Mineral Nutrition in Higher Plants, Academic Press Limited, London.

McFarlane, G., Pulkownik, A., Burchet, M., 2003. Accumulation and distribution of heavy metals in grey mangrove, Avicennia marina (Forsk.) Vierh.: biological indication potential. Environmental Pollution 123, 139-151.

Meagher, R., 2000. Phytoremediation of toxic elemental and organic pollutants, Current Opinion in Plant Biology 3, 153-162.

Mitsch, W., Gosselink, J., 2000. Wetlands, John Wiley \& Sons, Inc. New York, pp. 920.

Neckles, H., Neill, C., 2004. Hydrologic control of litter decomposition in seasonally flooded prairie marshes. Hydrobiologia. 286, 155-165. 
452 Otte, M., 1991. Heavy metals and arsenic in vegetation of salt marshes and floodplains. $453 \quad$ PhD thesis, Vrije Universiteit. Amsterdam

454 Oven, M., Grill, E., Golan-Goldhirsh, A., Kutchan, T., Zenk, M., 2002. Increase of free 455 cystein and citric acid in plant cells exposed to cobalt ions. Phytochemistry 60, 456 467-474.

457 Rozema, J., Otte, R., Broekman, R., Punte, H., 1985. Accumulation of heavy metals in 458 estuarine salt marsh sediment and uptake of heavy metals by salt marsh 459 halophytes In: Lekkas T, editor. International Conference Heavy Metals in the 460 Environment, Athenes, Greece, 545-547.

461 Salgueiro, N., Caçador, I., 2007. Short-term sedimentation in Tagus estuary, Portugal: the influence of salt marsh plants. Hydrobiologia 587, 185-193.

463 Sokal, R., Rohlf, F., 1981. Biometry, 2nd edition, W.H. Freeman and Co, San Francisco

464 Sundby, B., Vale, C., Caetano, M., Luther, G., 2003. Redox chemistry in the root zone

465 of a salt marsh sediment in the Tagus estuary, Portugal. Aquatic Geochemistry $4669,257-271$.

467 Sundby, B., Caetano, M., Vale, C., Gobeil, C., Luther, G., Nuzzio, D., 2005. Root468 induced cycling of lead in salt marsh sediments. Environmental Science 469 Technology 39, 2080-2086.

470 Vale, C., 1990. Temporal variations of particulate metals in the Tagus river estuary. $471 \quad$ Science Total Environment 97/98, 137-154.

472 Valiela, I., Teal, J., Allen, S., van Etten, R., Goehringer, D. Volkmann, S., 1985.

473 Decomposition in salt marsh ecosystems: the phases and major factors affecting

474 disappearance of aboveground organic matter. Journal Experimental Marine 475 Biology Ecology 89, 29-54.

476 Valiela, I., Rutecki, D., Fox, S., 2004. Salt marshes: biological controls of food webs in 477 a diminishing environment. Journal of Experimental Marine Biology and $478 \quad$ Ecology 300, 131- 159.

479 Weis, J., Weis, P., 2004. Metal uptake, transport and release by wetland plants:

480 implications for phytoremediation and restoration. Environmental International $481 \quad 30,685-700$.

482 Weis, P., Windham, L., Burke, D., Weis, J., 2002. Release into the environment of 483 metals by two vascular salt marsh plants. Marine Environmental Research 54, 484 325-329. 
485 Williams, J., 2002. Phytoremediation in wetland ecosystems: Progress, problems, and 486 potential. Critical Reviews Plant Science 21, 607-635.

487 Windham, L., Weis, J., Weis, P., 2003. Uptake and distribution of metals in two

488 dominant salt marsh macrophytes, Spartina alterniflora (cordgrass) and

489 Phragmites australis (common reed) Estuarine Coastal Shelf Science 56, 63-72.

490 Zawislanski, P., Chau, S., Mountford, H., Wong, H., Sears, T., 2001. Accumulation of

491 selenium and trace metals on plant litter in a tidal marsh, Estuarine Coastal Shelf

$492 \quad$ Science 52, 589-603.

493 Zenk, M., 1996. Heavy metal detoxification in higher plants - a review. Gene 179, 21-

$494 \quad 30$. 
497 Figure 1 - Location of the Tagus estuary and Rosário salt marsh.

498

499 Figure 2 - Whole plant standing stock of each metal. Values presented as mean \pm SD.

500

501 Figure 3 - Standing stocks of $\mathrm{Zn}, \mathrm{Cu} \mathrm{Co}$ and $\mathrm{Cd}$ for aboveground tissues of S. fruticosa,

502 S. perennis, H. portulacoides and S. maritima. Values presented as mean \pm SD.

503 Dissimilar letters denote significant differences $(p<0.05)$.

504

505 


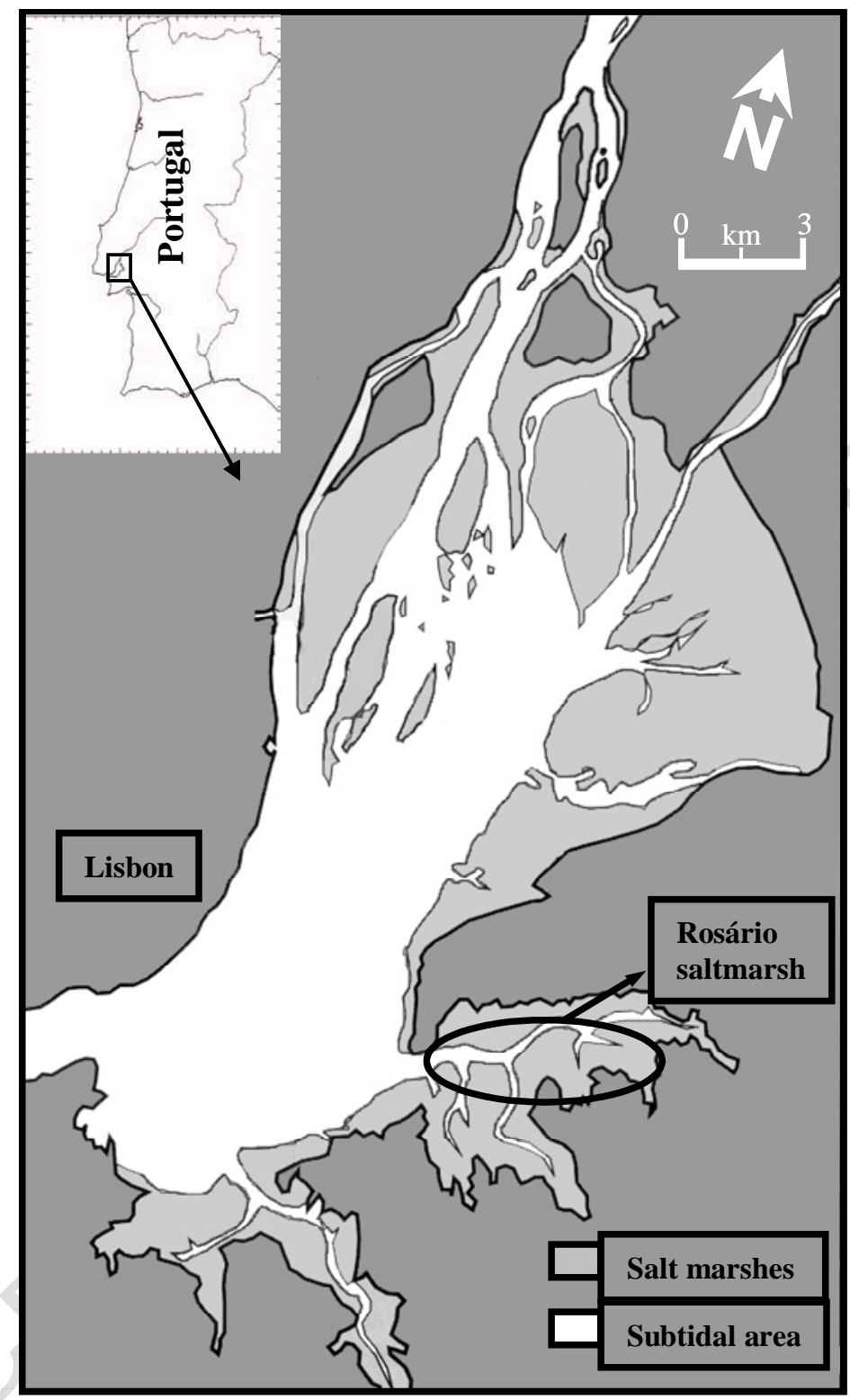

Figure 1 

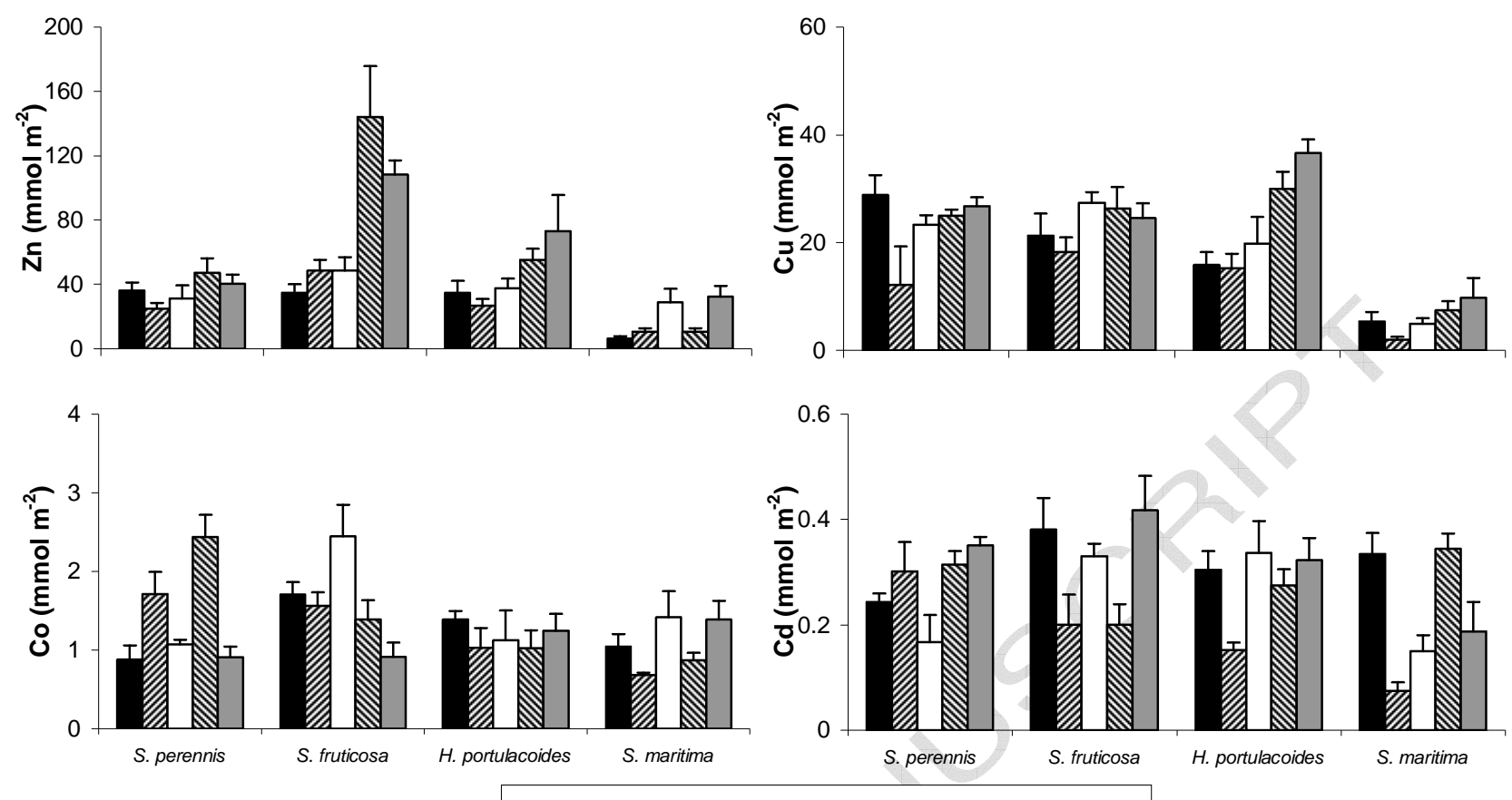

$\square$ Oct.01 $\square$ Dec.01 $\square$ Feb.02 \$Apr.02 $\square$ Jun.02

Figure 2 

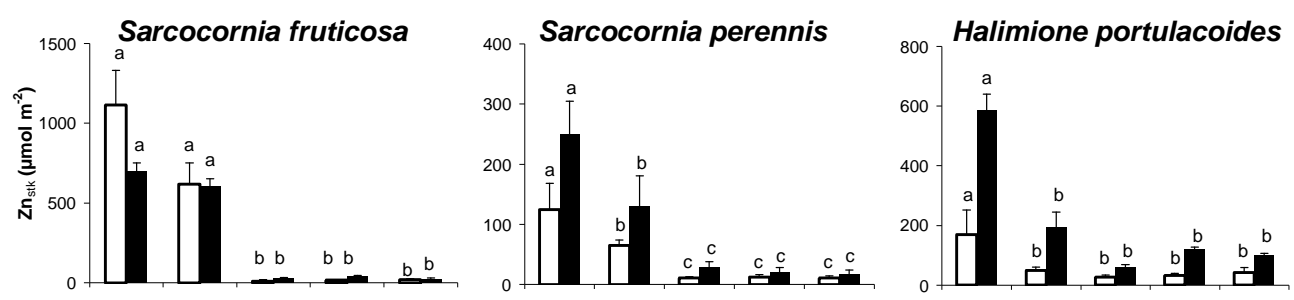

Spartina maritima
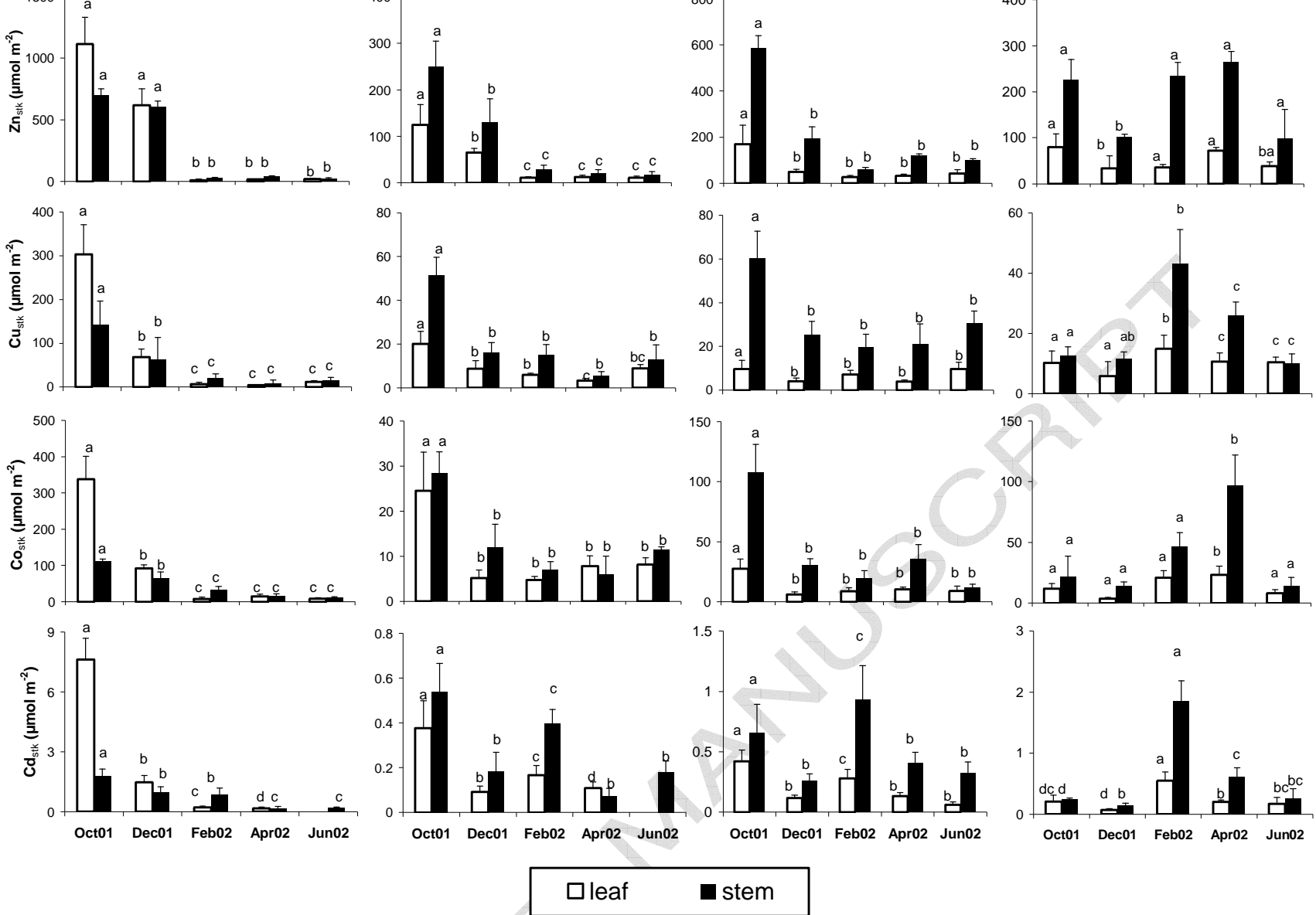

口leaf

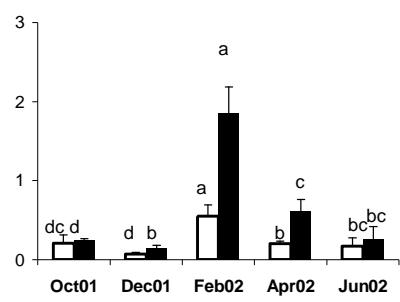

Figure 3 
Table 1 - Average $(n=5) \mathrm{pH}$ and redox potential $(\mathrm{Eh}, \mathrm{mV})$ in rooting sediment of $S$. fruticosa, S. perennis, H. portulacoides, and S. maritima.

\begin{tabular}{llcc}
\hline & & pH & Eh $(\mathbf{m V})$ \\
\cline { 3 - 4 } Sarcocornia & Dec. & 6.9 & $17 \pm 11$ \\
fruticosa & Feb. & $7.3 \pm 0.1$ & $-6 \pm 10$ \\
& Apr. & $7.4 \pm 0.1$ & $-25 \pm 9$ \\
& Jun. & 7.9 & $34 \pm 13$ \\
Sarcocornia & Dec. & $6.3 \pm 0.3$ & $43 \pm 10$ \\
perennis & Feb. & 7.7 & $34 \pm 14$ \\
& Apr. & $7.5 \pm 0.1$ & $73 \pm 7$ \\
& Jun. & 7.9 & $125 \pm 19$ \\
Halimione & Dec. & 7.0 & $44 \pm 10$ \\
portulacoides & Feb. & 7.9 & $67 \pm 8$ \\
& Apr. & 7.7 & $84 \pm 7$ \\
& Jun. & 8.0 & $0 \pm 10$ \\
Spartina & Dec. & $6.6 \pm 0.1$ & $91 \pm 7$ \\
maritima & Feb. & 7.8 & $98 \pm 7$ \\
& Apr. & 7.7 & $93 \pm 8$ \\
& Jun. & 7.8 & $90 \pm 12$ \\
\hline
\end{tabular}

Table 1 
Table 2 - Average concentrations $(n=5)$ and standard deviations of $\mathrm{Zn}, \mathrm{Cu}, \mathrm{Co}$ and $\mathrm{Cd}$ $\left(\mu \mathrm{mol} \mathrm{g}{ }^{-1}\right)$ in rooting sediment of $S$. fruticosa, S. perennis, H. portulacoides, and S. maritima all over the seasonal survey.

\begin{tabular}{lll}
\hline & Species & Sediment \\
\cline { 2 - 3 } $\mathrm{Zn}\left(\mu \mathrm{mol} \mathrm{g}{ }^{-1}\right)$ & S. fruticosa & $3.6 \pm 0.2$ \\
& S. perennis & $5.4 \pm 0.5$ \\
& H. portulacoides & $4.5 \pm 0.2$ \\
& S. marítima & $4.0 \pm 0.4$ \\
$\mathrm{Cu}\left(\mu \mathrm{mol} \mathrm{g}^{-1}\right)$ & S. fruticosa & $0.62 \pm 0.03$ \\
& S. perennis & $0.63 \pm 0.02$ \\
& H. portulacoides & $0.63 \pm 0.03$ \\
$\mathrm{Co}\left(\mu \mathrm{mol} \mathrm{g}{ }^{-1}\right)$ & S. marítima & $0.72 \pm 0.02$ \\
& S. fruticosa & $0.48 \pm 0.01$ \\
& S. perennis & $0.57 \pm 0.02$ \\
& H. portulacoides & $0.57 \pm 0.02$ \\
& S. marítima & $0.70 \pm 0.01$ \\
$\mathrm{Cd}\left(\mu \mathrm{mol} \mathrm{g}{ }^{-1}\right)$ & S. fruticosa & $0.029 \pm 0.001$ \\
& S. perennis & $0.027 \pm 0.001$ \\
& H. portulacoides & $0.026 \pm 0.0003$ \\
& S. marítima & $0.028 \pm 0.0002$ \\
\hline
\end{tabular}

Table 2 
Table 3 - Average $(n=5)$ dry weight biomass $\left(\mathrm{g} \mathrm{m}^{-2}\right)$ and standard deviations for total and individual plant tissues of $S$. fruticosa, $S$. perennis, $H$. portulacoides, and $S$. maritima.

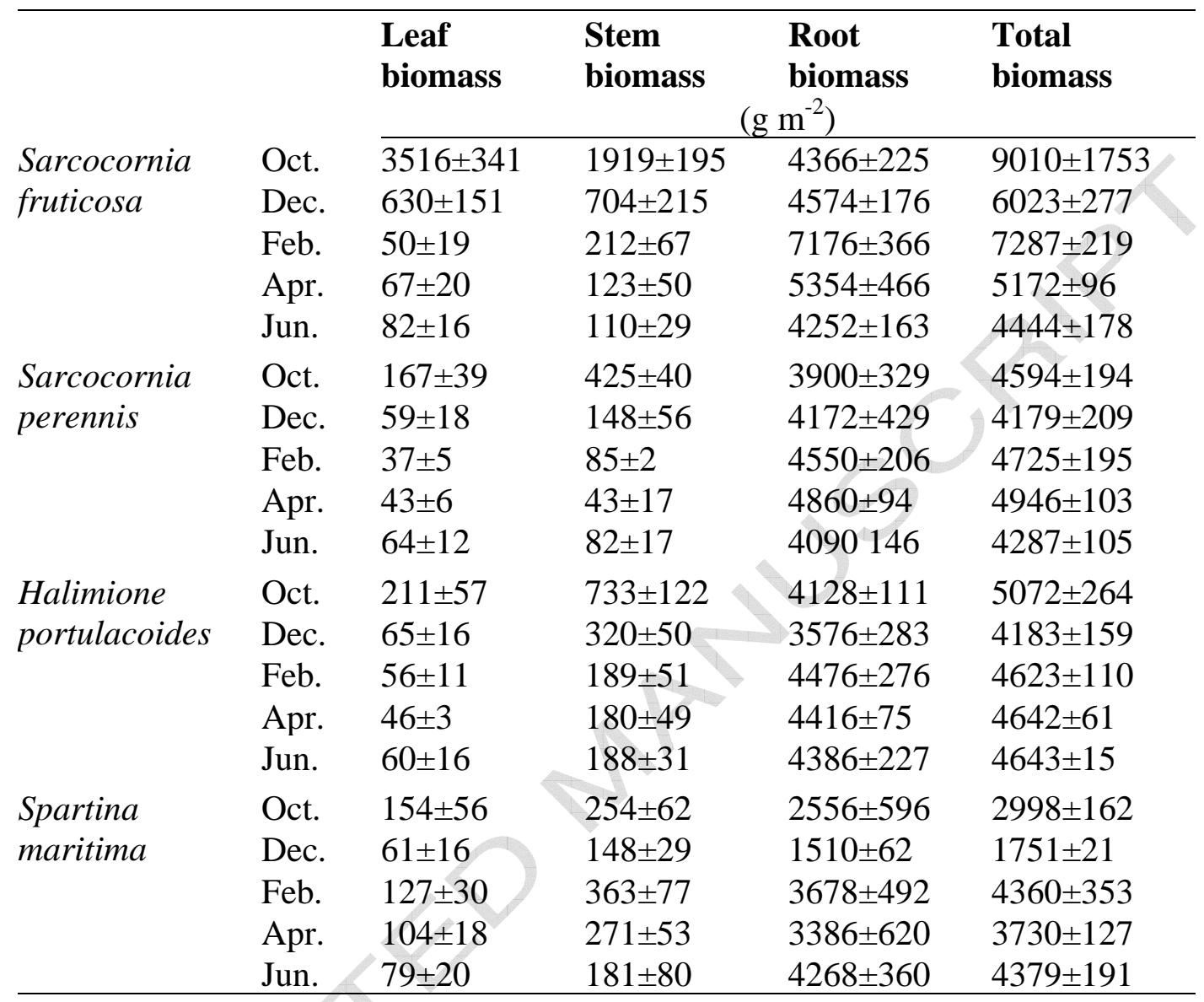

Table 3 
Table 4 - Metal concentrations for individual plant tissues of S. fruticosa, S. perennis, H. portulacoides, and S. maritima.

\begin{tabular}{|c|c|c|c|c|c|c|c|c|c|c|c|c|c|}
\hline \multirow{5}{*}{$\begin{array}{l}\text { Sarcocornia } \\
\text { fruticosa }\end{array}$} & \multirow{6}{*}{$\begin{array}{l}\text { Oct. } \\
\text { Dec. } \\
\text { Feb. }\end{array}$} & \multicolumn{4}{|l|}{ leaf } & \multicolumn{4}{|l|}{ stem } & \multicolumn{4}{|l|}{ root } \\
\hline & & \multirow{2}{*}{\multicolumn{4}{|c|}{$\left(\mu \mathrm{mol.g} \mathrm{g}^{-1}\right)^{\text {Co }}$}} & $\mathrm{Zn}$ & $\mathrm{Cu}$ & $\mathrm{Co}$ & $\mathrm{Cd}$ & $\mathrm{Zn}$ & $\mathrm{Cu}$ & $\mathrm{Co}$ & $\mathrm{Cd}$ \\
\hline & & & & & & \multicolumn{4}{|c|}{$\left(\mu \mathrm{mol} . \mathrm{g}^{-1}\right)$} & \multicolumn{4}{|c|}{$\left(\mu \mathrm{mol} \cdot \mathrm{g}^{-1}\right)$} \\
\hline & & $0.36 \pm 0.05$ & $0.071 \pm 0.011$ & $0.051 \pm 0.008$ & $0.00089 \pm 0.0001$ & $0.45 \pm 0.14$ & $0.076 \pm 0.017$ & $0.097 \pm 0.008$ & $0.0021 \pm 0.0001$ & $8.1 \pm 3.9$ & $4.8 \pm 0.87$ & $0.26 \pm 0.06$ & $0.087 \pm 0.024$ \\
\hline & & $0.83 \pm 0.20$ & $0.089 \pm 0.008$ & $0.085 \pm 0.004$ & $0.0014 \pm 0.0001$ & $1.0 \pm 0.3$ & $0.11 \pm 0.01$ & $0.14 \pm 0.01$ & $0.0023 \pm 0.0001$ & $10 \pm 1$ & $4.0 \pm 0.54$ & $0.29 \pm 0.05$ & $0.048 \pm 0.014$ \\
\hline & & $0.12 \pm 0.03$ & $0.095 \pm 0.013$ & $0.15 \pm 0.01$ & $0.0040 \pm 0.0004$ & $0.21 \pm 0.07$ & $0.13 \pm 0.03$ & $0.14 \pm 0.01$ & $0.0045 \pm 0.0007$ & $8.7 \pm 3.0$ & $3.8 \pm 0.38$ & $0.31 \pm 0.06$ & $0.049 \pm 0.008$ \\
\hline & Apr. & $0.31 \pm 0.05$ & $0.067 \pm 0.014$ & $0.16 \pm 0.01$ & $0.0014 \pm 0.0002$ & $0.24 \pm 0.04$ & $0.057 \pm 0.011$ & $0.23 \pm 0.05$ & $0.0023 \pm 0.0003$ & $26 \pm 3$ & $4.5 \pm 0.94$ & $0.29 \pm 0.08$ & $0.038 \pm 0.007$ \\
\hline & Jun. & $0.22 \pm 0.05$ & $0.14 \pm 0.02$ & $0.11 \pm 0.01$ & $0.0017 \pm 0.0003$ & $0.23 \pm 0.05$ & $0.14 \pm 0.02$ & $0.096 \pm 0.007$ & - & $23 \pm 6$ & $5.7 \pm 0.64$ & $0.20 \pm 0.05$ & $0.091 \pm 0.020$ \\
\hline \multirow{5}{*}{$\begin{array}{l}\text { Sarcocornia } \\
\text { perennis }\end{array}$} & Oct. & $0.59 \pm 0.11$ & $0.12 \pm 0.01$ & $0.069 \pm 0.013$ & $0.0013 \pm 0.0002$ & $0.74 \pm 0.16$ & $0.12 \pm 0.01$ & $0.14 \pm 0.02$ & $0.0022 \pm 0.0003$ & $8.2 \pm 2.7$ & $6.8 \pm 1.9$ & $0.19 \pm 0.04$ & $0.065 \pm 0.007$ \\
\hline & Dec. & $0.90 \pm 0.20$ & $0.11 \pm 0.03$ & $0.095 \pm 0.003$ & $0.0012 \pm 0.0003$ & $1.2 \pm 0.3$ & $0.15 \pm 0.04$ & $0.092 \pm 0.017$ & $0.0016 \pm 0.0001$ & $5.6 \pm 1.3$ & $3.6 \pm 2.0$ & $0.37 \pm 0.09$ & $0.069 \pm 0.012$ \\
\hline & Feb. & $0.34 \pm 0.11$ & $0.18 \pm 0.05$ & $0.083 \pm 0.023$ & $0.0047 \pm 0.0008$ & $0.29 \pm 0.04$ & $0.16 \pm 0.01$ & $0.14 \pm 0.01$ & $0.0045 \pm 0.0009$ & $5.8 \pm 2.7$ & $5.1 \pm 0.21$ & $0.29 \pm 0.11$ & $0.037 \pm 0.012$ \\
\hline & Apr. & $0.47 \pm 0.05$ & $0.13 \pm 0.01$ & $0.13 \pm 0.06$ & $0.0017 \pm 0.0002$ & $0.29 \pm 0.06$ & $0.077 \pm 0.017$ & $0.18 \pm 0.04$ & $0.0026 \pm 0.0006$ & $9.8 \pm 2.9$ & $5.1 \pm 0.27$ & $0.44 \pm 0.12$ & $0.059 \pm 0.011$ \\
\hline & Jun. & $0.22 \pm 0.07$ & $0.15 \pm 0.06$ & $0.15 \pm 0.02$ & $0.0022 \pm 0.0003$ & $0.17 \pm 0.04$ & $0.14 \pm 0.02$ & $0.13 \pm 0.02$ & - & $9.5 \pm 1.6$ & $6.8 \pm 0.77$ & $0.22 \pm 0.03$ & $0.090 \pm 0.010$ \\
\hline \multirow{5}{*}{$\begin{array}{l}\text { Halimione } \\
\text { portulacoides }\end{array}$} & Oct. & $0.77 \pm 0.19$ & $0.083 \pm 0.017$ & $0.14 \pm 0.01$ & $0.00087 \pm 0.0002$ & $0.77 \pm 0.23$ & $0.046 \pm 0.009$ & $0.14 \pm 0.01$ & $0.0020 \pm 0.0003$ & $9.5 \pm 3.4$ & $4.4 \pm 1.5$ & $0.27 \pm 0.08$ & $0.074 \pm 0.007$ \\
\hline & Dec. & $0.62 \pm 0.16$ & $0.080 \pm 0.019$ & $0.10 \pm 0.01$ & $0.0008 \pm 0.0001$ & $0.79 \pm 0.19$ & $0.063 \pm 0.018$ & $0.10 \pm 0.02$ & $0.0018 \pm 0.0002$ & $8.5 \pm 2.6$ & $4.8 \pm 1.4$ & $0.28 \pm 0.06$ & $0.042 \pm 0.001$ \\
\hline & Feb. & $0.31 \pm 0.09$ & $0.11 \pm 0.02$ & $0.11 \pm 0.01$ & $0.0049 \pm 0.0002$ & $0.50 \pm 0.09$ & $0.13 \pm 0.03$ & $0.16 \pm 0.03$ & $0.0050 \pm 0.0006$ & $8.2 \pm 1.5$ & $4.8 \pm 1.3$ & $0.25 \pm 0.09$ & $0.075 \pm 0.016$ \\
\hline & Apr. & $0.71 \pm 0.26$ & $0.11 \pm 0.03$ & $0.21 \pm 0.02$ & $0.0023 \pm 0.0005$ & $0.71 \pm 0.15$ & $0.088 \pm 0.014$ & $0.23 \pm 0.03$ & $0.0029 \pm 0.0006$ & $12 \pm 2$ & $6.7 \pm 0.7$ & $0.21 \pm 0.05$ & $0.066 \pm 0.092$ \\
\hline & Jun. & $0.53 \pm 0.08$ & $0.16 \pm 0.02$ & $0.067 \pm 0.004$ & $0.0017 \pm 0.0003$ & $0.71 \pm 0.24$ & $0.14 \pm 0.03$ & $0.14 \pm 0.03$ & $0.0010 \pm 0.0002$ & $17 \pm 1$ & $7.5 \pm 1.0$ & $0.28 \pm 0.05$ & $0.082 \pm 0.017$ \\
\hline \multirow{5}{*}{$\begin{array}{l}\text { Spartina } \\
\text { maritima }\end{array}$} & Oct. & $0.78 \pm 0.21$ & $0.051 \pm 0.008$ & $0.11 \pm 0.02$ & $0.0010 \pm 0.0002$ & $0.48 \pm 0.07$ & $0.066 \pm 0.008$ & $0.079 \pm 0.019$ & $0.0013 \pm 0.0004$ & $2.4 \pm 0.4$ & $2.0 \pm 0.2$ & $0.37 \pm 0.04$ & $0.15 \pm 0.02$ \\
\hline & Dec. & $0.71 \pm 0.15$ & $0.075 \pm 0.008$ & $0.091 \pm 0.006$ & $0.00094 \pm 0.0001$ & $0.68 \pm 0.10$ & $0.12 \pm 0.03$ & $0.063 \pm 0.014$ & $0.0010 \pm 0.0002$ & $6.5 \pm 1.6$ & $1.3 \pm 0.3$ & $0.41 \pm 0.06$ & $0.045 \pm 0.017$ \\
\hline & Feb. & $0.48 \pm 0.15$ & $0.12 \pm 0.01$ & $0.13 \pm 0.01$ & $0.00051 \pm 0.0005$ & $0.27 \pm 0.02$ & $0.12 \pm 0.02$ & $0.16 \pm 0.01$ & $0.0043 \pm 0.0002$ & $7.2 \pm 1.8$ & $1.4 \pm 0.3$ & $0.39 \pm 0.05$ & $0.041 \pm 0.009$ \\
\hline & Apr. & $1.00 \pm 0.19$ & $0.091 \pm 0.009$ & $0.35 \pm 0.03$ & $0.0020 \pm 0.0003$ & $0.79 \pm 0.04$ & $0.10 \pm 0.01$ & $0.23 \pm 0.01$ & $0.0020 \pm 0.0001$ & $3.4 \pm 0.6$ & $2.2 \pm 0.3$ & $0.26 \pm 0.06$ & $0.11 \pm 0.03$ \\
\hline & Jun. & $0.49 \pm 0.15$ & $0.12 \pm 0.03$ & $0.070 \pm 0.009$ & $0.0014 \pm 0.0004$ & $0.51 \pm 0.22$ & $0.22 \pm 0.13$ & $0.11 \pm 0.01$ & $0.0022 \pm 0.0006$ & $6.7 \pm 1.9$ & $2.3 \pm 0.9$ & $0.29 \pm 0.08$ & $0.049 \pm 0.015$ \\
\hline
\end{tabular}

Table 4 